\title{
Mycobacterium avium infection in BALB/c and SCID mice
}

\author{
LANFRANCO FATTORINI, MAURIZIO MATTEI*, ROBERTA PLACIDO†, BO LI§, ELISABETTA IONA, \\ UMBERTO AGRIMI , VITTORIO COLIZZI* and GRAZIELLA OREFICI
}

Laboratory of Bacteriology and Medical Mycology, Istituto Superiore di Sanità, Rome, *Department of Biology, Laboratory of Molecular Pathology and Immunochemistry, "Tor Vergata" University, Rome, †I.R.C.C.S. Santa Lucia, Rome and $¥$ Laboratory of Veterinary Medicine, Istituto Superiore di Sanità, Rome, Italy

\begin{abstract}
BALB/c and severe combined immunodeficient (SCID) mice were inoculated intraperitoneally with Mycobacterium avium and the numbers of cfu were monitored for $\mathbf{7 0}$ days in spleen, liver, lung, kidney, brain and peritoneum. While BALB/c mice formed typical granulomas and controlled bacterial growth in organs, a delay in development of lesions and a modest containment of infection were observed in SCID mice. In the spleen of BALB/c mice, in which bacterial growth was contained, macrophages (Mo) and natural killer $(\mathrm{NK})$ cell numbers increased $\geqslant 4.2$ times and $T$ - and B-cell numbers increased $\geqslant 1.8$ times after 42 days of infection; conversely, a low recruitment of mononuclear cells was observed in the spleen of SCID mice, where M. avium proliferated efficiently. Unlike visceral organs, a pronounced decrease in the number of cfu was observed in the peritoneum of BALB/c mice, concomitantly with a $\geqslant 31.7$-fold increase in Mo and NK cells and $a \geqslant 9.1$-fold increase in $T$ and $B$ cells. In the peritoneum of SCID mice only a bacteriostatic effect was observed despite a $\geqslant 56.7$-fold increase in Mo and NK cells and $a \geqslant 22.3$-fold increase in $T$ and $B$ cells. These results suggest that while an intact immune response can efficiently control $M$. avium infection in the spleen and peritoneum of BALB/c mice, cells of the innate immune system such as Mo and NK cells play a role in the containment of bacterial growth in the peritoneum, but not spleen, of SCID mice.
\end{abstract}

\section{Introduction}

Disseminating disease caused by Mycobacterium avium is the most common form of bacterial infection in HIVinfected patients. The disease is most often seen in patients with very low $\mathrm{CD} 4^{+}$T-cell counts and has been shown to contribute significantly to mortality [1].

Resistance to infection with bacterial pathogens in normal hosts with an intact immune system requires the co-ordinated interaction of both innate and acquired cellular immunity [2]. Macrophages (Mø) and natural killer (NK) cells operate in the former system while $\mathrm{CD}^{+}$and $\mathrm{CD} 8^{+} \mathrm{T}$ cells are the main components of the latter [3]. In immunocompetent

Received 23 March 1998; revised version received 29 Sept. 1998; accepted 7 Oct. 1998.

Corresponding author: Dr G. Orefici (e-mail: Marella@iss.it). §Present address: National Institute for the Control of Pharmaceutical and Biological Products, Division of Pharmacology, Temple of Heaven, Beijing, China. mice it has been shown that $\mathrm{CD}^{+}$but not $\mathrm{CD} 8^{+} \mathrm{T}$ cells $[4,5]$ play a major role in the control of $M$. avium infection, but other cell populations such as NK cells may be involved in early protection $[2,3,6]$. In the past, severe combined immunodeficient (SCID) mice, which are known to lack functional $\mathrm{B}$ and $\mathrm{T}$ cells [7], were used to study chronic infections with intracellular parasites $[4,8-11]$ to which they were more susceptible than immunocompetent mice. Such mice exhibit a cellular immune system operating without the modulation of $\mathrm{B}$ or $\mathrm{T}$ cells, that is, without acquired immunity, but retain normal function of $\mathrm{NK}$ cells and Mø [2].

In this study, both SCID and immunocompetent $(\mathrm{BALB} / \mathrm{c})$ mice were infected intraperitoneally with $M$. avium and bacterial growth and granuloma formation were examined at various times. In addition, a cytofluorometric examination of peritoneal and spleen cells was performed to investigate the pattern of inflammatory cells generated within compartments with different levels of anti- $M$. avium activity. 


\section{Materials and methods}

Mice

Specific pathogen-free BALB/c mice were obtained from Charles River (Calco, Lecco, Italy). CB-17 scid/scid (SCID) mice were purchased from Iffa Credo (Lyon, France). Male mice, aged 6-7 weeks, were used throughout the study. The animals were bred and maintained under barrier conditions, and fed sterilised chow and acidified water ad libitum.

\section{Micro-organism and infection of mice}

A clinical isolate of $M$. avium obtained from an AIDS patient (strain 485, type 21, transparent colonies [12]), was used throughout the study. Colonies grown on Middlebrook 7H10 Agar plates (Difco Laboratories) were suspended in phosphate-buffered saline (PBS) and sonicated briefly. A suspension adjusted to an optical density of 0.2 at $500 \mathrm{~nm}$ (corresponding to $c$. $6 \times 10^{8} \mathrm{cfu} / \mathrm{ml}$ ) was prepared. Mice were inoculated intraperitoneally with graded doses of mycobacteria $\left(10^{6}, 10^{7}\right.$ or $10^{8} \mathrm{cfu} / \mathrm{mouse}$, five mice/dose/time point $)$ in $0.2 \mathrm{ml}$ of PBS. At different time points mice were killed and $4 \mathrm{ml}$ of sterile PBS were injected into the peritoneum. The fluid was withdrawn and added to an equal volume of Middlebrook $7 \mathrm{H} 9$ Broth (Difco). After a brief sonication (10 s, Soniprep 150; MSE, Crawley) the suspension was serially 10 -fold diluted and plated on to $7 \mathrm{H} 10$ agar medium. Colonies were counted after incubation for $10-14$ days at $37^{\circ} \mathrm{C}$ in a humidified $\mathrm{CO}_{2}$ $5 \%$ atmosphere and the numbers of $\mathrm{cfu} / \mathrm{ml}$ in recovered peritoneal fluid were determined. The organs collected under aseptic conditions were suspended in 7H9 medium, ground in homogenisers and briefly sonicated. The numbers of $\mathrm{cfu} / \mathrm{g}$ of organ were determined as described above.

\section{Histopathological studies}

A histopathological study was performed on spleen, liver, lung, kidney and brain tissues. Portions of each organ collected at 21 and 56 days after infection were fixed in neutral formalin $10 \%$ for 1 week and embedded in paraffin. Sections of organs ( $5 \mu \mathrm{m}$ thick) were stained either with haematoxylin and eosin or by the Ziehl-Neelsen acid-fast method.

\section{Flow cytometry}

Cells were stained with fluorescein isothiocyanate or phycoerythrin-conjugated anti-CD4 (RM4-5, IgG2a), anti-CD8 (53-6.7, IgG2a), anti-B cells (B220, RA36B2, IgG2a), anti-macrophage (Mø) Ly-6C (AL-21, IgM), anti-natural killer (NK) cells (5E6, IgG2a) monoclonal antibodies (MAbs; Pharmingen, San Diego, CA, USA). Cells incubated with MAbs $\left(1 \mu \mathrm{g} / 10^{6}\right.$ cells) on ice for $30 \mathrm{~min}$ were washed three times with PBS containing fetal calf serum $1 \%$ and sodium azide $0.2 \%$ and treated with a lysing solution (Becton
Dickinson Immunocytochemical Systems, San Jose, CA, USA). The cells were resuspended in $0.5 \mathrm{ml}$ of FACS flow solution and analysed in a FACScan apparatus (Becton Dickinson) with Lysis II software. Data were reported as means and SEM and compared by Student's $t$ test.

\section{Results}

Pathogenicity of $M$. avium for $B A L B / c$ and $S C I D$ mice

When inoculated with $10^{8} \mathrm{cfu}, \mathrm{BALB} / \mathrm{c}$ mice resisted the infection, none was killed by this dose within 70 days. In contrast, this inoculum was lethal for SCID mice, which all died between 49 and 70 days. A dose of $10^{7} \mathrm{cfu} /$ mouse did not cause any deaths in either strain; this dose was then chosen to study chronic infection during a 70-day period (Fig. 1). After $24 \mathrm{~h}, c$. 15 and $30 \%$ of the inoculum was still present in the peritoneum of BALB/c and SCID mice, respectively, and c. $1-2 \%$ of the micro-organisms were found in liver, spleen, lung and, at a lower level, in kidney and brain.

In $\mathrm{BALB} / \mathrm{c}$ mice, a substantial containment of infection was seen in lung and kidney, while in liver and spleen a plateau in cfu number was preceded in the first 21 days by an increase in the number of cfu of 1.5 and $2 \log _{10}$, respectively. In brain, but even more in peritoneum, a remarkable reduction in cfu was seen, followed by a late regrowth at 8-9 weeks. In SCID mice, a constant increase in the number of cfu was seen, reaching a maximum in the kidney (4 $\log _{10}$ ); viable counts increased $>3 \log _{10}$ in spleen and lung and $>2 \log _{10}$ in liver. In brain, after a $1 \log _{10}$ increase in the first week, the number of cfu remained constant up to 70 days; in peritoneum, the infection was contained from the onset and no relevant variation in the number of cfu was observed with time.

\section{Development and morphology of granulomas}

In spleen of BALB/c mice, granulomas formed by aggregates of epithelioid Mø mostly located in and around the marginal zone at the periphery of lymph follicles were observed on day 21 (Fig. 2a). On day 56, these granulomas were still present as small accumulations of epithelioid cells inside the follicles (Fig. 2b) and occasionally contained intracellular mycobacteria. On day 21, splenic granulomas larger than those observed in BALB/c mice were found in SCID mice (Fig. 2c); these lesions appeared to be increased on day 56 (Fig. 2d) and contained a high number of intracellular mycobacteria.

Granulomas were evident in liver of BALB/c mice, on day 21 (Fig. 2e) and decreased in size on day 56 (Fig. 2f). In SCID mice, on day 21, liver lesions appeared as focal accumulations of myelomonocytic cells 

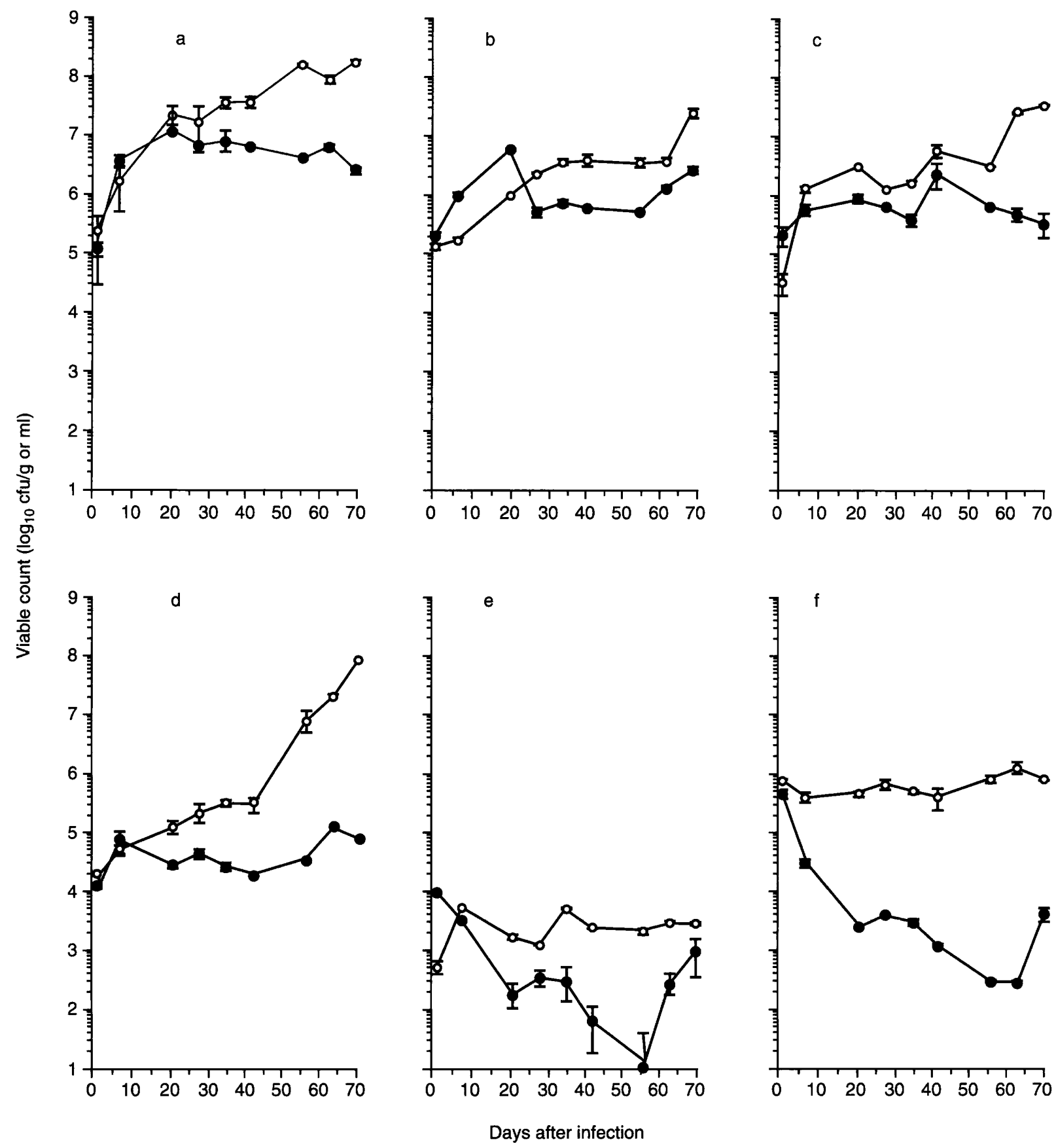

Fig. 1. Time course of $M$. avium infection in (a) spleen, (b) liver, (c) lung, (d) kidney, (e) brain and (f) peritoneum of SCID $(0)$ and BALB/c $(\bullet)$ mice inoculated with $1 \times 10^{7} \mathrm{cfu}$ intraperitoneally. Results represent the mean and SD cfu/g of organ or $\mathrm{cfu} / \mathrm{ml}$ of peritoneal lavage in each group at each time point.

lacking the lymphocytic cuff seen in BALB/c mice (Fig. 2g); their size had increased on day 56 (Fig. 2h). At the latter time, isolated Kupffer cells heavily filled with mycobacteria but not surrounded by inflammatory infiltrates were frequently seen in SCID but not $\mathrm{BALB} / \mathrm{c}$ mice.

In lung, epithelioid granumolas with few mycobacteria were occasionally observed in BALB/c mice on days 21 (Fig. 3a) and 56. At the latter time point, rare aggregates of heavily infected Mø resembling small granulomas were observed in the lung of SCID mice; in some cases, accumulation of infected inflammatory cells within the adjacent bronchial lumen was seen
(Fig. 3b). No lesions were evident in kidney and brain of either mouse strain.

\section{Cytofluorometric analysis of $B A L B / c$ and $S C I D$} mice cells

To investigate the nature of immune cells generated during infection, flow cytometry analysis of spleen (Table 1) and peritoneal cells (Table 2) was performed on day 42. Cells of uninfected mice (controls) were examined at the same time.

$\mathrm{BALB} / \mathrm{c}$ mice spleen controls $\left(130 \times 10^{6}\right.$ total cells $)$ contained $45 \%$ B cells, $24 \% \mathrm{M} \varnothing, 13 \% \mathrm{CD}^{+} \mathrm{T}$ cells, 

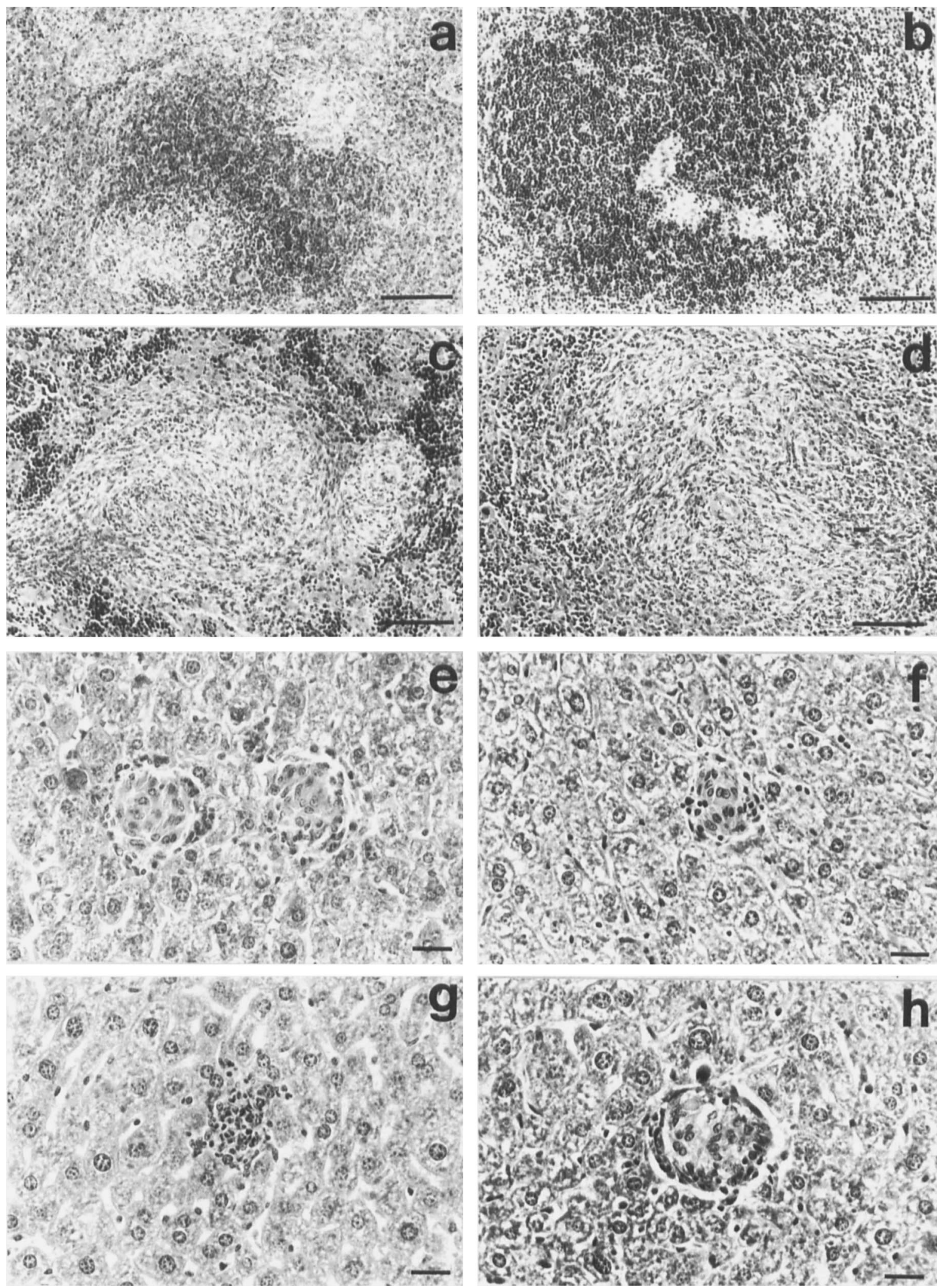

Fig. 2. Haematoxylin and eosin-stained sections of $M$. avium-induced lesions in spleen (a-d) and liver (e-h) of BALB $/ \mathrm{c}$ and SCID mice inoculated with $1 \times 10^{7} \mathrm{cfu}$ intraperitoneally. Bar $=35 \mu \mathrm{m}$. a, BALB $/ \mathrm{c}$ mice, 21 days, spleen; b, BALB/c mice, 56 days, spleen; c, SCID mice, 21 days, spleen; d, SCID mice, 56 days, spleen; e, BALB/c mice, 21 days, liver; f, BALB/c mice, 56 days, liver; g, SCID mice, 21 days, liver; $\mathbf{h}$, SCID mice, 56 days, liver.

$10 \% \mathrm{CD}^{+} \mathrm{T}$ cells and $3 \% \mathrm{NK}$ cells. Following infection, the total spleen cell number was raised 2fold, with $a \geqslant 4$-fold increase in the absolute number of Mø (47\% of the total) and NK cells and a 2-, 3- and 2-fold increase in the absolute numbers of $\mathrm{CD} 4^{+}$, $\mathrm{CD}^{+}$and $\mathrm{B}$ cells, respectively; some cells showed a double positivity, as shown by total marker percentages being higher than $100 \%$. 


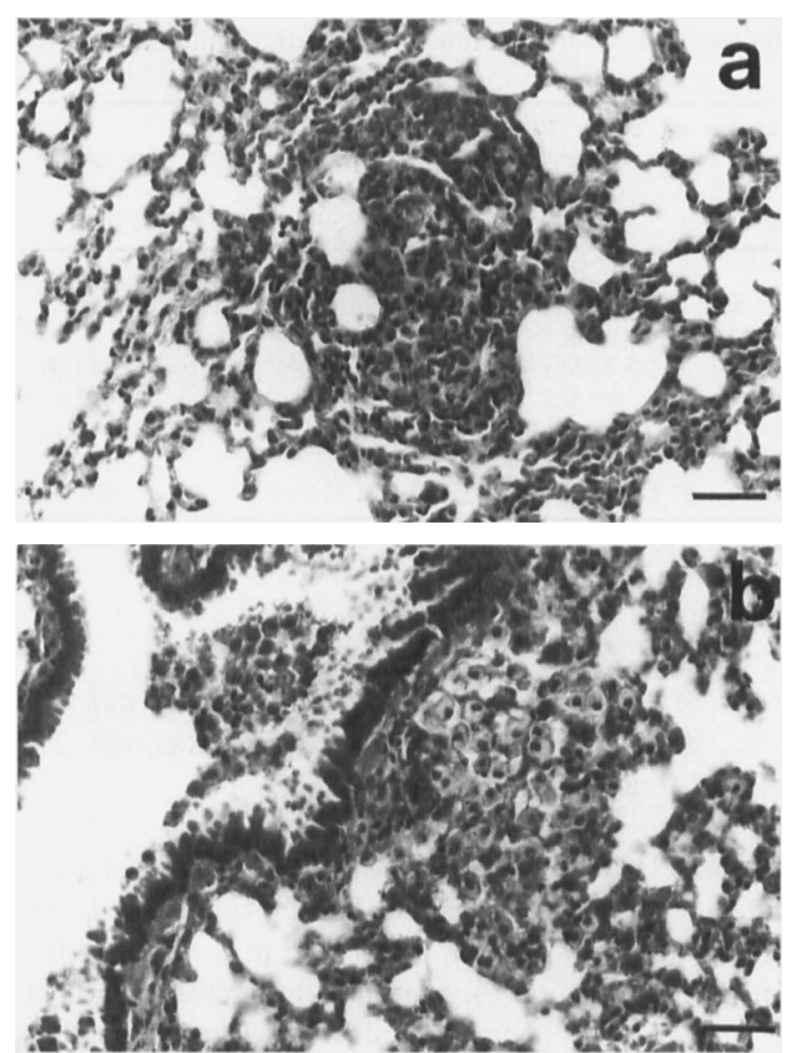

Fig. 3. Haematoxylin and eosin-stained sections of $M$ avium-induced lesions in lung of mice inoculated with $1 \times 10^{7} \mathrm{cfu}$ intraperitoneally. Bar $=35 \mu \mathrm{m}$. a, BALB $/ \mathrm{c}$ mice, 21 days after infection; $b$, SCID mice, 56 days after infection.

In spleens of uninfected SCID mice $\left(35 \times 10^{6}\right.$ cells/spleen), $38 \%$ of the cells were not stained by any of the MAbs used and most of the stained cells were $\mathrm{Mø}$ and $\mathrm{NK}$ cells $(37 \%$ and $12 \%$ of the total, respectively). $M$. avium infection induced a two-fold increase in the total cell number with relatively low changes in the proportion of single cell populations.

In the peritoneal lavages of BALB/c mice, $55 \%$ of the cells were not stained by the MAbs used and a relevant proportion of the stained cells $(26 \%$ of the total) were B cells. After infection, the total cell number increased 6.4-fold and the absolute numbers of Mø and NK cells (38\% and $16 \%$ of the total, respectively) increased $\geqslant 32$-fold and those of $\mathrm{CD}^{+}$, $\mathrm{CD}^{+}$and $\mathrm{B}$ cells increased 12-, 14- and 9-fold, respectively.

A large increase in the total cell number (11.3-fold) and in the number of the single cell lineages was also induced by $M$. avium infection in the peritoneal cavity of SCID mice, with a $\geqslant 56.7$-fold increase in the absolute numbers of Mø and NK cells and a 22-, 55and 41 -fold increase in those of $\mathrm{CD}^{+}, \mathrm{CD}^{+}$and $\mathrm{B}$ cells, respectively.

\section{Discussion}

M. avium infection was more severe in SCID than in $\mathrm{BALB} / \mathrm{c}$ mice, although less progressive and lethal than that reported in SCID mice infected with BCG or M. tuberculosis $[9,10]$. This is in keeping with the knowledge that $M$. avium can cause disseminated infections in severely immunocompromised individuals such as AIDS patients and focal diseases limited to lungs in normal hosts [1]. After intraperitoneal inoculation of $10^{8} \mathrm{cfu}$, SCID mice died between days 49 and 70 while they survived $>70$ days with an inoculum of $10^{7} \mathrm{cfu}$; these results confirm and extend previous observations $[4,11]$ and show that even in mice devoid of functional $\mathrm{T}$ and $\mathrm{B}$ cells a partial containment of $M$. avium infection can be obtained. It is difficult to correlate the results of mortality in mice with human infections; indeed, various mycobacterial loads are found at the post-mortem examination of $M$. avium-infected AIDS patients [13,14], but it should also be noted that in these patients the primary cause of death is not always the M. avium infection.

Bacterial counts were contained in BALB/c mice, after a period of rapid increase in the number of cfu, and a clear decreasing trend was observed in peritoneum and brain. In SCID mice, control of bacterial multiplication was seen in the peritoneum and brain, but not in other organs. The end of the first

Table 1. Cytofluorometric analysis of spleen cells in uninfected and $M$. avium-infected BALB/c and SCID mice on day 42

\begin{tabular}{|c|c|c|c|c|c|c|}
\hline \multirow[b]{2}{*}{ Group } & \multicolumn{6}{|c|}{ Mean number of cells $\times 10^{6 *}(\%)$} \\
\hline & $\begin{array}{l}\text { Total } \\
\text { cells }\end{array}$ & $\begin{array}{l}\mathrm{CD}^{+} \\
\mathrm{T} \text { cells }\end{array}$ & $\begin{array}{l}\mathrm{CD}^{+} \\
\mathrm{T} \text { cells }\end{array}$ & Mø & B cells & NK cells \\
\hline Uninfected BALB/c & 130 & $\begin{array}{c}16.2 \\
(12.5 \text { SEM 4.8) }\end{array}$ & $\begin{array}{c}12.7 \\
(9.8 \text { SEM } 0.7)\end{array}$ & $\begin{array}{c}31.5 \\
(24.2 \text { SEM 4.7) }\end{array}$ & $\begin{array}{c}58.1 \\
\text { (44.7 SEM 2.9) }\end{array}$ & $\begin{array}{c}4.3 \\
\text { (3.3 SEM 0.1) }\end{array}$ \\
\hline Infected $\mathrm{BALB} / \mathrm{c}$ & 280 & $\begin{array}{c}28.8 \\
(10.3 \mathrm{SEM} 2.5)\end{array}$ & $\begin{array}{c}36.4 \\
\text { (13 SEM 2.1) }\end{array}$ & $\begin{array}{c}132.4 \\
(47.3 \text { SEM } 0.3)^{\dagger}\end{array}$ & $\begin{array}{c}106.7 \\
\text { (38.1 SEM 1.5) }\end{array}$ & $\begin{array}{c}19.3 \\
(6.9 \mathrm{SEM} 1.3)^{\dagger}\end{array}$ \\
\hline Uninfected SCID & 35 & $\begin{array}{c}1.4 \\
(4 \mathrm{SEM} 1.2)\end{array}$ & $\begin{array}{c}0.6 \\
\text { (1.6 SEM 0.5) }\end{array}$ & $\begin{array}{c}13.1 \\
\text { (37.4 SEM 1.7) }\end{array}$ & $\begin{array}{c}2.3 \\
(6.6 \mathrm{SEM} 0.9)\end{array}$ & $\begin{array}{c}4.3 \\
(12.3 \text { SEM } 0.8)\end{array}$ \\
\hline Infected SCID & 71 & $\begin{array}{c}2.1 \\
(3 \text { SEM } 0.6)\end{array}$ & $\begin{array}{c}0.6 \\
(0.9 \text { SEM } 0.4)\end{array}$ & $\begin{array}{c}30 \\
\text { (42.2 SEM 3.1) }\end{array}$ & $\begin{array}{c}5.8 \\
\text { (8.2 SEM 1.7) }\end{array}$ & $\begin{array}{c}6.8 \\
\text { (9.6 SEM 1.2) }\end{array}$ \\
\hline
\end{tabular}

\footnotetext{
* Data shown are representative of two experiments $(n=3$ mice per group in each experiment).
}

${ }^{\dagger} \mathrm{p}<0.05$, compared with percentage in uninfected mice, Student's $t$ test. 
Table 2. Cytofluorometric analysis of peritoneal cells in uninfected and $M$. avium-infected BALB/c and SCID mice on day 42

\begin{tabular}{|c|c|c|c|c|c|c|}
\hline \multirow[b]{2}{*}{ Group } & \multicolumn{6}{|c|}{ Mean number of cells $\times 10^{4 *}(\%)$} \\
\hline & $\begin{array}{l}\text { Total } \\
\text { cells }\end{array}$ & $\begin{array}{l}\mathrm{CD4}^{+} \\
\mathrm{T} \text { cells }\end{array}$ & $\begin{array}{l}\mathrm{CD}^{+} \\
\mathrm{T} \text { cells }\end{array}$ & Mø & B cells & NK cells \\
\hline Uninfected BALB/c & 250 & $\begin{array}{c}17.5 \\
(7 \text { SEM } 1)\end{array}$ & $\begin{array}{c}6.2 \\
(2.5 \text { SEM } 1.5)\end{array}$ & $\begin{array}{c}15 \\
(6 \text { SEM } 0.8)\end{array}$ & $\begin{array}{c}65 \\
\text { (26 SEM 1.4) }\end{array}$ & $\begin{array}{c}8.2 \\
\text { (3.3 SEM } 0.3)\end{array}$ \\
\hline Infected BALB/c & 1,600 & $\begin{array}{c}208 \\
(13 \text { SEM } 1.3)^{\dagger}\end{array}$ & $\begin{array}{c}88 \\
\text { (5.5 SEM 1.5) }\end{array}$ & $\begin{array}{c}608 \\
(38 \mathrm{SEM} 1.4)^{\dagger \dagger}\end{array}$ & $\begin{array}{c}592 \\
(37 \text { SEM } 1.5)^{\dagger}\end{array}$ & $\begin{array}{c}260 \\
(16.2 \text { SEM } 1.8)^{\dagger}\end{array}$ \\
\hline Uninfected SCID & 30 & $\begin{array}{c}0.7 \\
\text { (2.3 SEM 0.2) }\end{array}$ & $\begin{array}{c}0.2 \\
(0.7 \text { SEM } 0.2)\end{array}$ & $\begin{array}{c}0.3 \\
(1.1 \text { SEM } 0.1)\end{array}$ & $\begin{array}{c}0.3 \\
(1 \text { SEM } 0.2)\end{array}$ & $\begin{array}{c}0.15 \\
(0.5 \text { SEM } 0.1)\end{array}$ \\
\hline Infected SCID & 340 & $\begin{array}{c}15.6 \\
(4.6 \mathrm{SEM} 0.4)^{\dagger}\end{array}$ & $\begin{array}{c}10.9 \\
(3.2 \text { SEM } 0.9)^{\dagger}\end{array}$ & $\begin{array}{c}41.1 \\
(12.1 \text { SEM } 1)^{\dagger \dagger}\end{array}$ & $\begin{array}{c}12.2 \\
(3.6 \mathrm{SEM} 0.6)^{\dagger}\end{array}$ & $\begin{array}{c}8.5 \\
(2.5 \text { SEM } 0.1)^{\dagger \dagger}\end{array}$ \\
\hline
\end{tabular}

${ }^{*}$ Data shown are representative of two experiments $(n=3$ mice/group in each experiment).

${ }^{\dagger} \mathrm{p}<0.05,{ }^{\dagger \dagger} \mathrm{p}<0.01$, compared with percentage in uninfected mice, Student's $t$ test.

phase of rapid bacterial multiplication (day 21) coincided in spleen and liver with the formation of granulomas with a typical structure in BALB/c mice and with a less compact aspect in SCID mice, which lasted throughout the following phase of chronic infection. Similar granulomas have been observed in spleen and liver of BCG-infected mice [9] and in liver of $M$. avium-infected SCID mice [11], where they were shown to be ineffective in containing the infection. While containment of the bacterial growth in the lung of BALB/c mice was associated with the formation of epithelioid granulomas, in SCID mice a tendency not to form granulomas even at late stages of infection was associated with a faster rate of bacterial growth in this organ, in keeping with that previously observed in BCG-infected SCID mice [9].

The comparison of mononuclear cells from spleens of uninfected or infected BALB/c mice and SCID mice showed that, in the first mouse strain, not only a significant increase in the Mø number could be observed (c. four times that seen in uninfected mice and half of the total cell number), but also a significant rise in NK cells. In uninfected SCID mice spleens - where the total cell number was about onequarter of that observed in BALB/c mice - a lower cellular response was found, in good accordance with the poor containment of bacterial growth in this organ. A close relationship between cellularity and resistance was also more evident in the peritoneum, where a massive increase in Mø and NK cells, and also in T and $\mathrm{B}$ cells, was associated with a rapid clearance of bacterial inoculum in infected BALB/c mice. In the peritoneum of uninfected SCID mice, not only was a paucity in $T$ and $B$ cells, in comparison with uninfected immunocompetent mice, found, but also a reduction in the number of $\mathrm{Mø}$ and $\mathrm{NK}$ cells, suggesting that the lack of functional $\mathrm{T}$ and $\mathrm{B}$ cells and of their products can markedly influence the recruitment and the functions of cells of the innate immune system in this region. However, the large increase in total mononuclear cells (including not only $\mathrm{Mø}$ and NK cells but also $\mathrm{CD}^{+}{ }^{+}$and $\mathrm{CD}^{+} \mathrm{T}$ cells and $\mathrm{B}$ cells) following infection allowed the contain- ment of the bacterial growth at the initial inoculum level, despite a total cell number which was only $21 \%$ of that found in infected BALB/c mice.

While $\mathrm{CD}^{+} \mathrm{T}$ cells are known to be involved in defence against $M$. avium in mice [4], $\mathrm{CD} 8^{+} \mathrm{T}$ cells are not known to play a direct role in the containment of murine infection $[4,5]$. Thus, the increase in $\mathrm{CD}^{+}$ $\mathrm{T}$ cells in peritoneum of both mouse strains could be explained by a general activation occurring in this compartment following peritoneal infection. A similar explanation can be given for the increase in B cells, whose role in protection is possibly not associated with production of antibodies (known to correlate with susceptibility to $M$. avium infection [15]), but more likely with their activity as antigen presenting cells [16]. Contemporary increases in NK cells and Mø in the peritoneum of both mouse strains are consistent with previous observations in which NK cells participated in $M$. avium resistance in mice through secretion of Mø-activating cytokines [11].

Therefore, a relevant decrease or containment of the number of cfu of $M$. avium at peritoneum level is not unexpected, because, unlike other non-tuberculous mycobacteria ( $M$. fortuitum, M. chelonei, M. gordonae) which have been implicated in human peritonitis $[17,18]$, to our knowledge, only one case of $M$. avium peritonitis in an AIDS patient [19] and four cases of peritonitis during continuous ambulatory peritoneal dialysis or liver disease [17, 20-22], have been described. Moreover, tuberculous peritonitis has been reported as the rarest form of extrapulmonary tuberculosis [23]. Rapid peritoneal clearance of micro-organisms in the peritoneum of immunocompetent hosts can be related both to intraperitoneal circulation [24] and acquisition of an activation state induced by cytokines secreted by the Mø themselves or mesothelium [25]. Relevant $M$. avium clearance by the peritoneal cavity has been reported in immunocompetent $\mathrm{Bcg}^{\mathrm{s}}$ and $\mathrm{Bcg}^{\mathrm{r}}$ mice, with the peritoneum of $\mathrm{Bcg}^{\mathrm{r}}$ mice being much more effective than that of $\mathrm{Bcg}^{\mathrm{s}}$ mice [26]. The observation of mycobacteriostatic activity in the peritoneum of SCID mice suggests that 
cells of the innate immune system such as Mø and NK cells are critical for effective inhibition of $M$. avium growth in this compartment.

Overall, these observations suggest the occurrence of a relevant response of serosal peritoneal surfaces to $M$. avium infection. This has also been observed in man for other body cavities such as the pleural space, which is known to react to $M$. tuberculosis by producing more T-helper 1 cytokines than blood [27], thus allowing patients with tuberculous pleuritis to mount an effective immune response to the infection. Taken together, the experimental evidence presented above and clinical observations in man can be used to facilitate further cellular or humoral studies of local host defences developed in the peritoneum against $M$. avium.

This work was supported in part by the Italian AIDS Project, Istituto Superiore di Sanità, Ministero della Sanità, Contract no. 10/A/Z. We thank Giovanna Alfarone and Laura Parisi (Istituto Superiore di Sanità) for valuable technical assistance.

\section{References}

1. Inderlied CB, Kemper CA, Bermudez LEM. The Mycobacterium avium complex. Clin Microbiol Rev 1993; 6: 266-310.

2. Bancroft GJ, Kelly JP. Macrophage activation and innate resistance to infection in SCID mice. Immunobiology 1994; 191: 424-431.

3. Kaufmann SHE. Immunity to intracellular microbial pathogens. Immunol Today 1995; 16: 338-342.

4. Appelberg R, Castro AG, Pedrosa J, Silva RA, Orme IM, Minóprio $P$. Role of gamma interferon and tumor necrosis factor alpha during T-cell-independent and -dependent phases of Mycobacterium avium infection. Infect Immun 1994; 62: 3962-3971.

5. Saunders MB, Cheers C. Inflammatory response following intranasal infection with Mycobacterium avium complex: role of T-cell subsets and gamma interferon. Infect Immun 1995; 63: $2282-2287$

6. Harshan KV, Gangadharam PRJ. In vivo depletion of natural killer cell activity leads to enhanced multiplication of Mycobacterium avium complex in mice. Infect Immun 1991; 59: 2818-2821.

7. Bosma GC, Custer RP, Bosma MJ. A severe combined immunodeficiency mutation in the mouse. Nature 1983; 301: 527-530.

8. Perryman LE, Mason PH, Chrisp CE. Effect of spleen cell populations on resolution of Cryptosporidium parvum infection in SCID mice. Infect Immun 1994; 62: 1474-1477.

9. North RJ, Izzo AA. Granuloma formation in severe combined immunodeficient (SCID) mice in response to progressive BCG infection. Tendency not to form granulomas in the lung is associated with faster bacterial growth in this organ. $A m J$ Pathol 1993; 142: 1959-1966.

10. North RJ, Izzo AA. Mycobacterial virulence. Virulent strains of Mycobacterium tuberculosis have faster in vivo doubling times and are better equipped to resist growth-inhibiting functions of macrophages in the presence and absence of specific immunity. J Exp Med 1993; 177: 1723-1733.

11. Hansch HCR, Smith DA, Mielke MEA, Hahn H, Bancroft GJ, Ehlers S. Mechanisms of granuloma formation in murine Mycobacterium avium infection: the contribution of $\mathrm{CD}^{+} \mathrm{T}$ cells. Int Immunol 1996; 8: 1299-1310.

12. Fattorini L, Vincent V, Li B et al. Type frequency and antimicrobial susceptibility of Mycobacterium avium-intracellulare complex strains isolated in Italy from AIDS and non AIDS patients. $J$ Chemother 1996; 173: 1030-1034.

13. Torriani FJ, Behling CA, McCutchan JA, Haubrich RH, Havlir DV. Disseminated Mycobacterium avium complex: correlation between blood and tissue burden. J Infect Dis 1996; 173: 942-949.

14. Wong B, Edwards FF. Kiehn TE et al. Continuous high-grade Mycobacterium avium-intracellulare bacteremia in patients with acquired immune deficiency syndrome. Am $J$ Med 1985; 78: 35-40.

15. Ferreira $P$, Soares R, Arala-Chaves M. Susceptibility to infection with Mycobacterium avium is paradoxically correlated with increased synthesis of specific anti-bacterial antibodies. Int Immunol 1991; 3: 445-452.

16. Vordermeier HM, Venkataprasad N, Harris DP, Ivanyi J. Increase of tuberculosis infection in the organs of $\mathrm{B}$ celldeficient mice. Clin Exp Immunol 1996; 106: 312-316.

17. Hakim A, Hisam N, Reuman PD. Environmental mycobacterial peritonitis complicating peritoneal dialysis: three cases and review. Clin Infect Dis 1993; 16: 426-431.

18. Harro C, Braden GL, Morris AB, Lipkowitz GS, Madden RL. Failure to cure Mycobacterium gordonae peritonitis associated with continuous ambulatory peritoneal dialysis. Clin Infect Dis 1997; 24: 955-957.

19. Perazella M, Eisen T, Brown E. Peritonitis associated with disseminated Mycobacterium avium complex in an acquired immunodeficiency syndrome patient on chronic ambulatory peritoneal dialysis. Am J Kidney Dis 1993; 21: 319-321.

20. Adal KA, Wispelwey B. Mycobacterium avium complex peritonitis in a patient with alcoholic liver disease. $J$ Clin Gastroenterol 1996; 22: 245-246.

21. Fernandez-Miranda C, Medina J, Palenque E, Martinez-Antonio E, Gonzalez-Gomez C. Peritonitis with Mycobacterium avium in a patient with hepatic cirrhosis. Am $J$ Gastroenterol 1993; 88: 615 .

22. Perlino CA. Mycobacterium avium complex: an unusual cause of peritonitis in patients undergoing continuous ambulatory peritoneal dialysis. Clin Inf Dis 1993; 17: 1083-1084.

23. Hopewell PC. Overview of clinical tuberculosis. In: Bloom BR (ed) Tuberculosis: pathogenesis, protection, and control. Washington, DC, ASM Press. 1994: 25-46.

24. Nance FC. Diseases of the peritoneum, retroperitoneum, mesentery, and omentum. In: Haubrich WS, Schaffner F, Berk JE (eds) Bockus Gastroenterology, 5th edn, vol 4. Philadelphia, WB Saunders. 1995: 3061-3105.

25. Eischen A, Duclos B, Schmitt-Goguel M et al. Human resident peritoneal macrophages: phenotype and biology. Br.J Haematol 1994; 88: 712-722.

26. Appelberg R, Sarmento AM. The role of macrophage activation and of $B c g$ - encoded macrophage function(s) in the control of Mycobacterium avium infection in mice. Clin Exp Immunol 1990; 80: 324-331.

27. Barnes PF, Modlin RL, Ellner JJ. T-cell responses and cytokines. In: Bloom BR (ed) Tuberculosis: pathogenesis, protection and control. Washington, DC, ASM Press. 1994: $417-435$. 